\title{
A case of recurrent Ludwig's angina
}

\section{Merwin Paul Remson Paul Raj*, Manoj Kumar Lohith Kumar, Anand Kesavan Hariharan, Srinivasan Krishnamoorthy}

Department of Otorhinolaryngology, Saveetha Medical College, Chennai, Tamil Nadu, India

Received: 19 February 2020

Revised: 29 April 2020

Accepted: 30 April 2020

\section{*Correspondence:}

Dr. Merwin Paul Remson Paul Raj,

E-mail: drmerwinpaul@gmail.com

Copyright: ( ) the author(s), publisher and licensee Medip Academy. This is an open-access article distributed under the terms of the Creative Commons Attribution Non-Commercial License, which permits unrestricted non-commercial use, distribution, and reproduction in any medium, provided the original work is properly cited.

\section{ABSTRACT}

In this paper, we describe the case of a 45-year-old male who presented with recurrent swelling of the submandibular region. The last episode of the swelling was triggered post tooth extraction. There were associated features like increased temperature and leukocytosis. The patient was started on IV antibiotics and analgesics and with incision and drainage the patient improved with no sequelae.

Keywords: Ludwig's angina, Recurrent infection, Submandibular infection

\section{INTRODUCTION}

Ludwig's angina is a submandibular space infection. It is a rapidly progressive, bilateral cellulitis of the supramylohyoid and inframylohyoid portions of the submandibular space. ${ }^{1}$ Some of the etiological factors include Odontogenic origin, infections of second or third molars. The predisposing factors include dental caries, recent dental treatment, systemic illnesses, immunocompromised states etc., ${ }^{2,3}$ With progressive swelling of the soft tissues and elevation and posterior displacement of the tongue, the most life-threatening complication of Ludwig's angina is airway obstruction. ${ }^{4}$ If it is left untreated it could even be fatal due to risk of asphyxia. Treatment consisting of aggressive antibiotics, surgical intervention and good dental care leads to a good prognosis.

\section{CASE REPORT}

We present a case of a 45-year-old male who came to us with chief complaints of pain and swelling below the jaw for 3 days duration. He described the pain to be of pricking type, which got aggravated on eating and relieved by medications. The patient mentioned that the swelling was progressive in nature. He also gave a similar history of pain and swelling below the jaw one month prior to the current episode post tooth extraction, which was treated by incision and drainage and IV antibiotics.

On initial work-up, the patient was found to be febrile with a temperature of $101^{\circ} \mathrm{F}$. His pulse was 104 BPM, blood pressure was $110 / 70 \mathrm{mmHg}$. Systemic examination was normal. On examination of the throat, floor of mouth was found to be edematous as shown in Figure $1 \mathrm{~A}$ and B. There was tenderness present in the submandibular region.

Laboratory investigations showed that his total leucocyte count was elevated $(18,100$ cells/cumm $)$. His absolute neutrophil count was also high (14,050 cells/cumm). The albumin level was found to be low $(2.9 \mathrm{~g} / \mathrm{dl})$. He was positive for $\mathrm{HbsAg}$. All the other routine laboratory parameters were within the normal range. 


\section{Imaging studies}

USG of the neck showed bilateral submandibular lymphadenopathy. CT scan of the neck showed diffuse cellulitis in sublingual space and bilateral submandibular spaces with cutaneous sinus with possible actinomycosis with superadded bacterial infection. In CECT of the neck, of 1st molar tooth was not visualized. There was a peripherally enhancing subcutaneous fluid collection in right submandibular region as seen in Figure 2A and B.
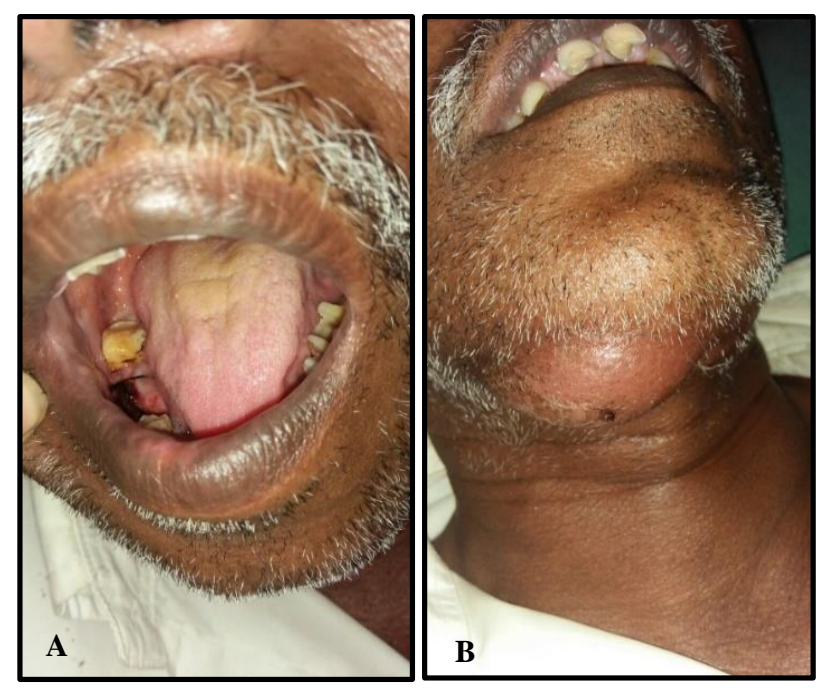

Figure 1: (A) Extracted tooth and (B) swelling in the submandibular region.

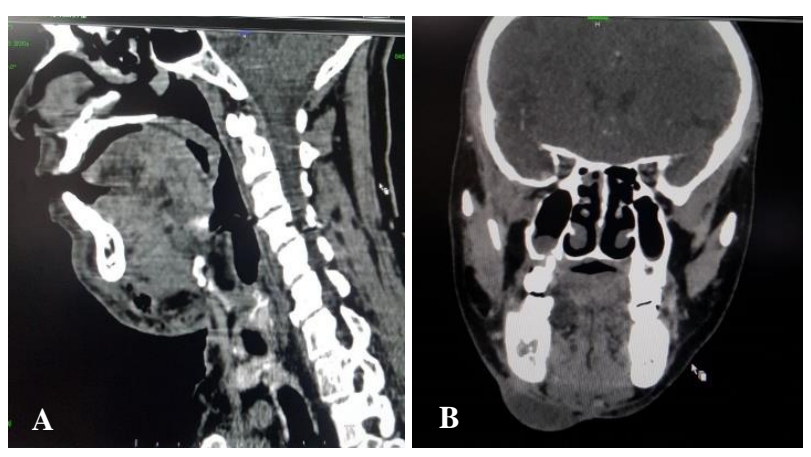

Figure 2: (A) Sagittal and (B) coronal views of the CT scan.

The patient was admitted and was started on fluids and IV antibiotics and analgesics. Incision and drainage were done which was followed by regular dressings. Subsequently the swelling subsided and the patient improved. There was no airway obstruction, hence tracheostomy was not done.

\section{DISCUSSION}

Ludwig's angina and deep neck infections are dangerous and they have a tendency to cause edema, distortion, and obstruction of airway. ${ }^{5}$ Observation and intravenous antibiotics like penicillin G, clindamycin or metronidazole will suffice to manage early stages of the disease. ${ }^{6}$ Advanced infections mandate for a surgical drainage. ${ }^{7}$ Some of the complications of Ludwig's angina include pain, trismus, airway edema, and tongue displacement creating a compromised airway. Tracheostomy using local anesthesia is the gold standard of airway management in patients with deep neck infections, but it may be difficult or impossible in advanced cases of infection because of anatomical distortion of the anterior neck. ${ }^{8}$

\section{CONCLUSION}

This case shows that even though primary treatment of the infection is administered to the patient a second trigger can lead to a recurrent infection in the submandibular space. Another finding is that this patient was positive for hepatitis B infection, hence further retrospective studies on patients with submandibular infection can be done to find an association between the same.

Funding: No funding sources Conflict of interest: None declared Ethical approval: Not required

\section{REFERENCES}

1. Snow J, Wackym P, Ballenger W. Ballenger's Otorhinolaryngology. Shelton, CT: Decker; 2009.

2. Fischmann GE, Graham BS. Ludwig's angina resulting from the infection of an oral malignancy. J Oral Maxillofac Surg. 1985;43:795-6.

3. Owens BM, Schuman NJ. Ludwig's angina. Gen Dent. 1994;42:84-7.

4. Bansal A, Miskoff J, Lis RJ. Otolaryngologic critical care. Crit Care Clin. 2003;19:55-72.

5. Moreland LW, Corey J, McKenzie R. Ludwig's angina. Report of a case and review of the literature. Arch Intern Med. 1988;148:461-6.

6. Har-El G, Aroesty JH, Shaha A, Lucente FE. Changing trends in deep neck abscess. A retrospective study of 110 patients. Oral Surg Oral Med Oral Pathol. 1994;77:446-50.

7. Bross-Soriano D, Arrieta_Gómez JR, PradoCalleros H, Schimelmitz-ldi J, Jorba-Basave S. Management of Ludwig's angina with small neck incisions: 18 years experience. Otolaryngol Head Neck Surg. 2004;130:712-7.

8. Busch RF, Shah D. Ludwig's angina: Improved treatment. Otolaryngol Head Neck Surg. 1997;117:172-5.

Cite this article as: Raj MPRP, Kumar MKL, Hariharan AK, Krishnamoorthy S. A case of recurrent Ludwig's angina. Int J Otorhinolaryngol Head Neck Surg 2020;6:1201-2. 